BULLETIN OF PNRPU. GEOLOGY. OIL \& GAS ENGINEERING \& MINING

ВЕСТНИК ПНИПУ. ГЕОЛОГИЯ. НЕФТЕГАЗОВОЕ И ГОРНОЕ ДЕЛО

ISSN 2224-9923

Volume/Tom 15 №20 2016

http://vestnik.pstu.ru/geo/

УДК 551.2; 539.3

Article / Статья

(C) PNRPU / ПНИПУ, 2016

\title{
ANALYSIS OF THE RESULTS OF SURVEYING AND GEODETIC OBSERVATIONS ON GEODYNAMIC TESTING GROUND SOUTH-PETIEGSKOIE FIELD
}

\section{lu.V. Vasilev}

West Siberian Branch of the Federal State Budgetary Institution of Science Institute of Petroleum Geology and Geophysics, named after A.A. Trofimuk, Siberian Branch of the Russian Academy of Sciences

(56 Volodarskogo, Tyumen, 625000, Russian Federation)

\section{АНАЛИЗ РЕЗУЛЬТАТОВ МАРКШЕЙДЕРСКО-ГЕОДЕЗИЧЕСКИХ НАБЛЮДЕНИЙ НА ГЕОДИНАМИЧЕСКОМ ПОЛИГОНЕ ЮЖНО-ПЕТЬЕГСКОГО МЕСТОРОЖДЕНИЯ}

\section{Ю.В. Васильев}

Западно-Сибирский филиал Федерального государственного бюджетного учреждения науки Института нефтегазовой геологии и геофизики им. А.А. Трофимука Сибирского отделения Российской академии наук (625000, Россия, г. Тюмень, ул. Володарского, 56)

Received / Получена: 27.06.2016. Accepted / Принята: 29.08.2016. Published / Опубликована: 30.09.2016

Key words:

contemporary geodynamic processes, geodynamic monitoring, dynamically stressed zones, geodynamic risk zone, high-precision geodetic and gravimetric measurements, geodynamic zoning, tectonic fault, Earth's surface subsidence's trough, industrial safety.

\begin{abstract}
Research and practical experience of operating oil and gas fields shows that the production of hydrocarbons produces a powerful anthropogenic impact on the geological environment, which leads to disruption of the stress-strain state of the field's subsurface array. It is not seldom accompanied by well accidents, cross-flows, aquifers pollution, can create conditions for settling the Earth's surface to a subsequent breach of stability and operational reliability of the oil and gas technological arrangement. In order to ensure industrial safety of oil and gas facilities in the South Petiegskoie field a geodynamic testing ground was created for a long-term surveying and geodetic observations and multiple repeated observations of contemporary deformation processes. The results of the third cycle of high-precision geodetic measurements obtained by geometric leveling of the class II, for the period 2014-2016 years, revealed that a greater number of observation points of the geodynamic testing ground heights gained significant negative values. This indicates a stable process of Earth's surface subsidence over the undermined territories mainly in the western part of the field, in the zone of maximum fluid and oil production. A geodynamic risk zone was revealed in the region of the well pad №1. Analysis and interpretation of geodynamic monitoring results (leveling of the class II, satellite observations, high-precision gravimetry), operating field development parameters (anthropogenic impact) and specificity of the natural geological and tectonic conditions allowed to determine that the condition for the formation of vertical and horizontal ground deformation was natural and man-made factor. The correlation between the formation of the Earth's surface subsidence`s trough and density characteristic's dynamics, accumulated oil production, reservoir pressures falling was revealed. Recommendations for the further conducting of geodynamic monitoring of the South Petiegskoie oil field were given.
\end{abstract}

Научно-практический опыт эксплуатации нефтегазовых месторождений свидетельствует о том, что добыча углеводородного сырья формирует мощное техногенное воздействие на геологическую среду, которое приводит к нарушению напряженно-деформированного состояния массива недр месторождения. Это нередко сопровождается авариями на скважинах, межпластовыми перетоками, загрязнением водоносных горизонтов, может создать условия для оседания земной поверхности с последующим нарушением устойчивости и эксплуатационной надежности технологических объектов нефтегазового обустройства. Для обеспечения промышленной безопасности объектов нефтегазодобычи на Южно-Петьегском месторождении создан геодинамический полигон для долговременного маркшейдерско-геодезического наблюдения, проведения многократных повторных наблюдений за современными деформационными процессами. Результаты третьего цикла высокоточных геодезических измерений, полученных геометрическим нивелированием II класса, за период 2014-2016 гг. выявили, что у большего числа наблюдательных пунктов геодинамического полигона высоты получили значительные отрицательные значения. Это свидетельствует о стабильном процессе оседания земной поверхности над подрабатываемой территорией, преимущественно в западной части месторождения, в зоне максимальных отборов жидкости и нефти. Выявлена зона геодинамического риска в районе площадки куста № 1. Анализ и интерпретация полученных результатов геодинамического мониторинга (нивелирование II класса, спутниковые наблюдения, высокоточная гравиметрия), эксплуатационных параметров разработки месторождений (техногенной нагрузки) и специфики природных геолого-тектонических условий позволили определить, что условием формирования вертикальных и горизонтальных деформаций земной поверхности является природно-техногенный фактор. Выявлена взаимосвязь формирования мульды оседания земной поверхности с динамикой плотностных характеристик, накопленной добычей нефти, падением пластовых давлений. Даны рекомендации по дальнейшему проведению геодинамического мониторинга на Южно-Петьегском нефтяном месторождении.

Iurii V. Vasilev - PhD in Geological and Mineralogical Sciences, senior researcher (mob. tel.: +007904 49683 55, e-mail: radan92@list.ru).

Васильев Юрий Владимирович - кандидат геолого-минералогических наук, старший научный сотрудник (моб. тел.: +007 90449683 55, e-mail: radan92@list.ru). 


\section{Introduction}

South-Petiegskoie oil field refers to Keumsk license block located in the territory of Uvatsky district of Tyumen region, in $125 \mathrm{~km}$ from Uvat settlement. The license block area is $4926 \mathrm{~km}^{2}$.

In 2007 in the scope of geological exploration work an appraisal well No.51 was drilled. Based on its testing, an oil field was discovered in $\mathrm{BS}_{6-7}$ horizon deposits of Ust-Balyk suite Lower Cretaceous region. The main horizon in terms of oil reserves in the field is $\mathrm{BS}_{6}(88 \%$ of the total volume of reserves), uncovered at a depth of 2290-2318 m, with total deposition thickness of $14 \mathrm{~m}$.

Geodynamic testing ground in SouthPetiegskoie field was created by RN-Uvat Neftegaz LLC in 2012 based on mining and geological substantiation and technical design project developed by Gornyie Technologii ("Mountain technologies") LLC in 2011. Earth surface subsidence was estimated at the level of $100 \mathrm{~mm}$ at reservoir pressure decrease by $10 \mathrm{MPa}$. Tyumen regional geodesic center LLC set up the testing ground, "zero", first, second and third cycles of survey and geodetic measurements, from 2012 to 2016 , respectively.

The works objective was to obtain quantitative parameters of vertical and horizontal drifts of earth surface as a result of hydrocarbon reserves development in order to ensure industrial safety of oil production facilities: process facilities of booster pump station (BPS), central gathering plant (CGP),well cluster pads [1, 2].

To insure industrial safety of the field in question and to identify conditions of contemporary deformation processes development, systemic approach was applied. The master plan of geodynamic monitoring included the entire scope of basic geodetic works (leveling, GNSS-observations, geophysics (high precision gravimetric analysis), earth remote probing (geodynamic zoning), oil-field geology (oil and fluid sampling, reservoir pressure). Analysis of geodynamic monitoring results according to this plan is required to determine the degree of geodynamic risk comprehensive assessment to substantiate administrative decisions in terms of oil and gas facilities operating reliability assurance $[3,4]$.

\section{Class II leveling works analysis}

High precision leveling was performed in order to obtain data on vertical deformations of reference points in the South-Petiegskoie geodynamical testing (GDTG). Leveling network diagram consisting of 4 lines hasn't been changed from 2013 to 2016. Total length of leveling lines amounted to $37 \mathrm{~km}$ of double run for 37 deep benchmarks (d.b.), including 4 versatile benchmarks (v.b.).

Office analysis results, assessment of stability and accuracy of measurements allow to conclude that leveling was performed with a root mean square of measurement equal to $0.8 \mathrm{~mm}$ for $1 \mathrm{~km}$ of double run [5].

The highest value of subsidence within the period of 2015-2016 was $249 \mathrm{~mm}$ (d.b. 24). Out of 37 points of South-Petiegskoie GDTG included in the scope of geometric leveling program 2016, at 28 the degradation of reference objects was captured. Altitude increase was registered in 5 reference points. Maximum altitude increase was observed at benchmark $16(+46 \mathrm{~mm})$.

During the observation period (2014-2016) 27 vertical degradation points out of 37 reference points were identified by way of leveling. The ultimate degradation value for the considered period amounted to $-376 \mathrm{~mm}$ (deep benchmark 17).

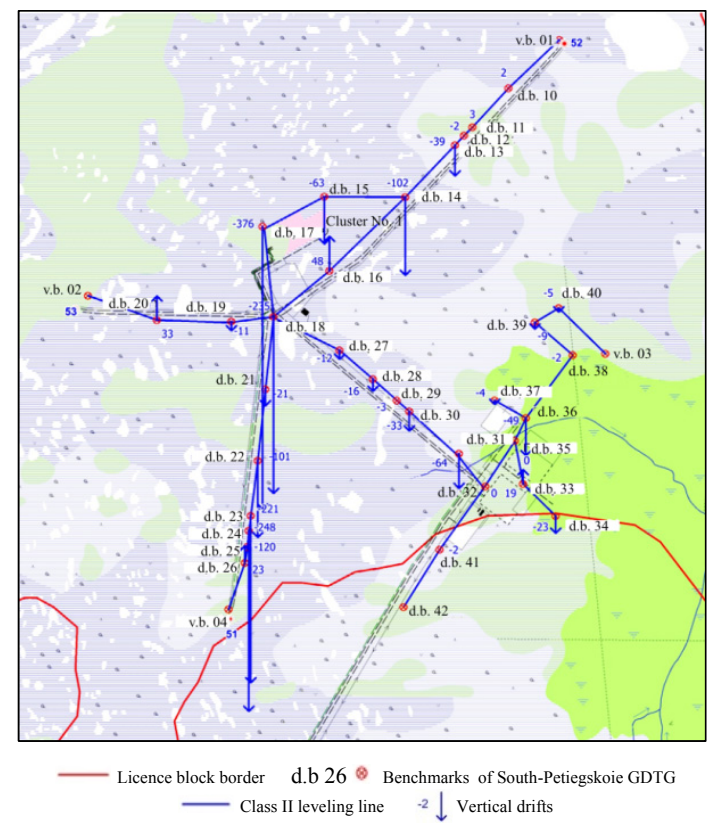

Figure 1. Schematic map of vertical deformations at South-Petiegskoie GDTG based on class II high precision leveling data for 2014-2016 
Overall, the results of the third cycle of high precision geodetic measurements obtained by class II geometric leveling for the period of 2014-2016 have shown that altitudes of most of the GDTG points have significantly degraded. This is an evidence of stable earth surface subsidence process over the developed territory in the western part of South-Petiegskoie field (Figure 1).

\section{Gravimetric changes analysis}

Gravity monitoring is aimed at identification of dynamic anomalies in the time of earth gravity on the daylight surface, caused by the changes of deep layers density properties. The main purpose of high precision gravimetrical analysis was to obtain data for geodynamic monitoring concerning local changes of non-tidal gravity field, since dynamic anomalies were caused by anthropogenic influence on geological environment in the process of field development [6].

Instrumental observations at South-Petiegskoie GDTG were performed with CG-5 [7] gravimetric equipment CG-5 [7] using the method of once-off measurements with central (original) point at the nominal level, without referencing the gravimetric objects to the state gravimetric network levels. Root mean square error of a single observation is $\pm 5 \mathrm{mcGal}$. Overall number of points in the network of gravity base stations - 36 benchmarks of geodynamic testing ground.

Office analysis of gravimetric data was performed in VECTOR [8] software. VECTOR system was developed specifically for geodynamic situation problem solving at oilfields and adjacent territories using gravimetric methods. It employs a method of micro test fields creation out of a multitude of points for further calculation of horizontal gradients using computerized trigonometry of the mapping area. This function allows optimizing a vastly inhomogeneous observation network:

- increasing the number of trigonometric elements for further calculation of gravity horizontal gradients;

- processing of quasiarea observation system (in which the observation scheme is a cloud of points) with further representation of materials in areal view;
- simplifying the input data entering procedure.

The procedure expands the scope of VECTOR system application to processing of arbitrary observation systems (when point-to-point distance may vary by a factor of 10) and allows presenting the materials in areal view.

In the scope of potential fields vector processing the procedure was developed for automatic calculation and modeling of gravity dynamic anomaly based on two series of observations from calculating the differences of horizontal gradients full vectors:

$$
\delta \Delta g_{\text {din }}(\Delta t)=\Delta g_{2}\left(t_{2}\right)-\Delta g_{1}\left(t_{1}\right),
$$

where $\delta \Delta g_{\text {din }}$ is dynamic gravity anomaly (variation in acceleration of gravity increase for time period $\Delta t) ; \Delta g_{2}$ - further observation during time period $t_{2} ; \Delta g_{1}$ - first observation during time period $t_{1}$.

At this relationship, the positive dynamic anomalies of gravity can be viewed as the increase of gravity field amplitude, while the negative ones - as its decrease. Thus based on the obtained values of gravity, abnormal increase areas were defined (compactification - territory subsidence) in the northern and southern parts of the field and decrease (decompaction - raise of territory) in the central part, which is an evidence of vertical drift of the earth due to the reserves development. The data is confirmed by the comparison analysis of leveling results and high precision gravimetrical analysis in the SouthPetiegskoie geodynamic testing ground by two observation cycles for 2015-2016 and for 20132016, see combined schematic maps and the profile (Figures 2-3).

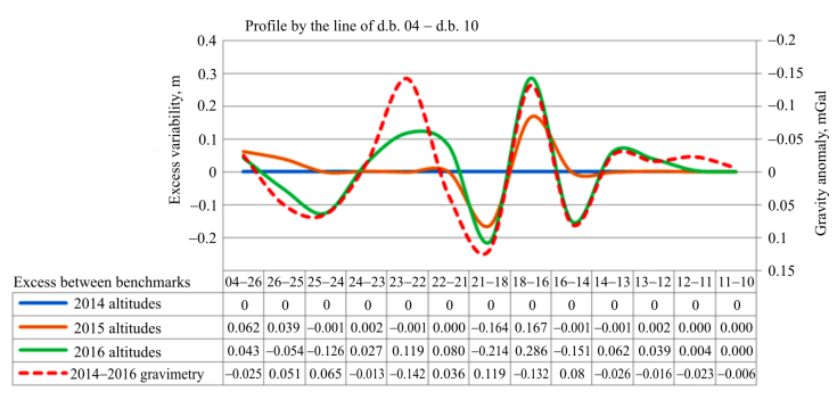

Figure 2. Dynamics of vertical deformations and density properties of earth gravity forces 


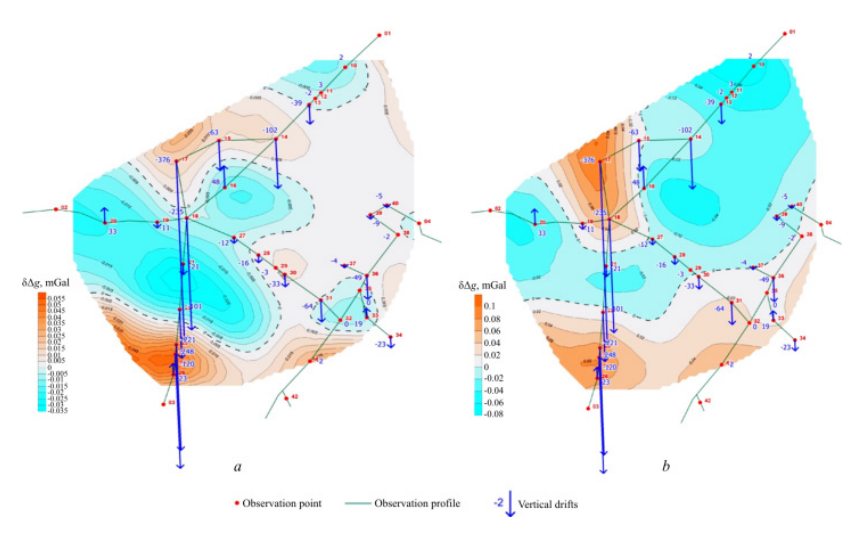

Figure 3. Combined leveling and gravimetric mapping results in South-Petiegskoie GDTG for the period: $a-2015-2016 ; b-2013-2016$.

\section{Analysis of satellite observations results}

High precision satellite geodetic observations at the points of South-Petiegskoie GDTG have been performed in order to receive the data on relative horizontal and vertical drifts of the earth surface. GNSS-observations program was planned in order to ensure direct measurements of all spatial vectors connecting adjacent points of the geodynamic testing ground for capturing of relative drifts of its earth surface areas.

Common geodetic network of SouthPetiegskoie GDTG csatellite monitoring was created in form of 36 point system varying by programs of observations and their role in the common network modeling task. The network central point is deep benchmark 35 (Figure 4).

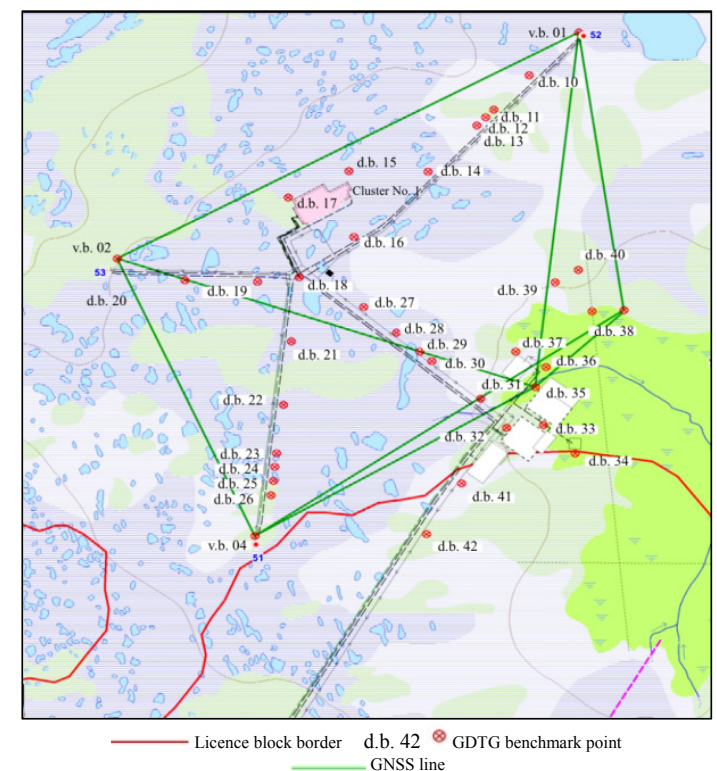

Figure 4. Base geodetic satellite network South-Petiegskoie geodynamic testing ground
Base point coordinates in ITRF system were defined relative to the adjacent points of the International Geodynamic system (IGS), namely ARTU (the city of Arti next to Ekaterinburg), NRIL (Norilsk) and NVSK (Novosibirsk), in the process of the first cycle of observations.

Long-term observations were conducted in the base points with short breaks related to data saving on removable storage devices and base points rearrangement. The observations were intended for increased frequency and homogeneity of operation together with all the other points in the network [9].

Based on the leveling of satellite geodetic measurements, the root mean square error for definition of plane coordinates of South-Petiegskoie GDTG centers in 2016 cycle amounted to $2.2 \mathrm{~mm}$. Root mean square error of points' geodetic altitudes determination amounted to $4.6 \mathrm{~mm}$.

Maximum values of horizontal drifts were received by benchmarks $15(98 \mathrm{~mm})$ and $17(71 \mathrm{~mm})$; these points were located next to well cluster No. 1. Other significant drifts were attributed to the benchmarks located next to the water ductwork under construction: Nos. 21 (33 mm), 22 (46 mm), $23(31 \mathrm{~mm}), 24(58 \mathrm{~mm})$ and $25(36 \mathrm{~mm})$.

Leveling and satellite observations results are shown on the schematic map of vertical and horizontal drifts where the presence of maximum vertical and horizontal deformations for observation points of geodynamic testing ground in the western part of the field can be ascertained (Figure 5).

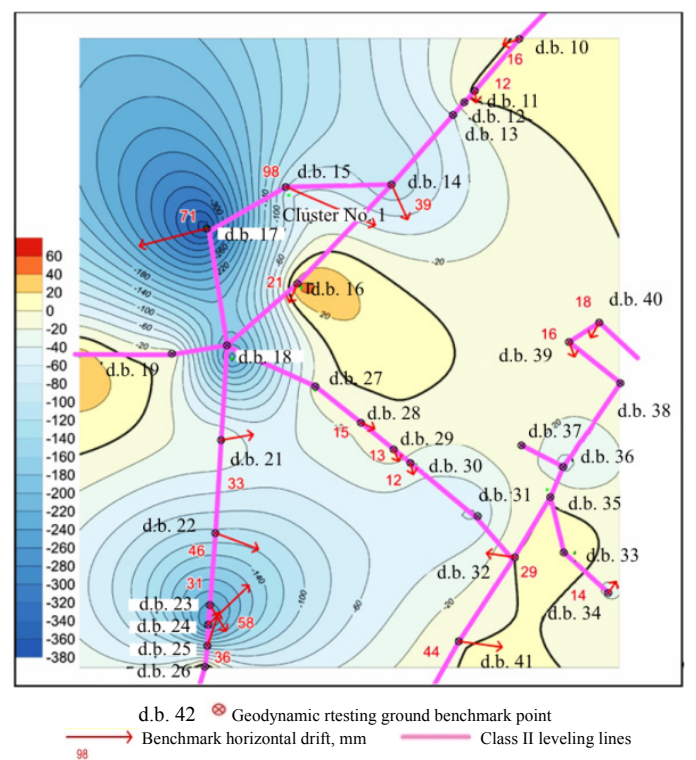

Figure 5. Isolines of vertical and horizontal deformations in South-Petiegskoie GDTG for 2014-2016 


\section{Analysis of natural geological and tectonic conditions}

Analysis of natural geological and tectonic conditions that define the nature of contemporary field geodynamics, form the stress-deformed state (SDS) of the field's subsurface mass and directly depend on the regional tectonic and gravitational field $[10,11]$. Tectonic and physical basics of the contemporary geodynamics describe geodynamic processes are a complex of interrelated deformational, seismic, geochemical and fluid dynamics phenomena occurring, as a rule, in the areas of local structural inhomogeneity of geological environment (tectonic faults, natural and anthropogenic fracturing, density inhomogeneity) [12-14].

Therefore, the work on identification of relation between fracture structures based on materials of seismic 3D survey updated in 2015 (Tyumen oil research center LLC) and geodynamic zoning was continued, including identification of dynamically stressed zones (DSZ) that reflect the disjunctive tectonic elements on the earth surface (Figure 6).

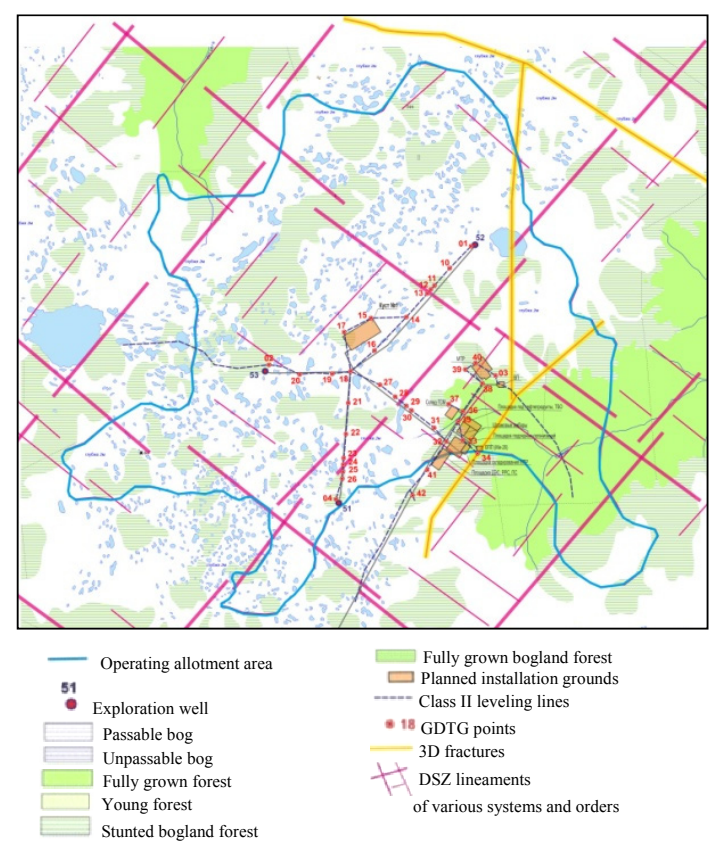

Figure 6. Schematic map of geodynamic zoning in South-Petiegskoie field

Summarizing and analysis of research materials on geotectonic conditions permitted to confirm previous conclusions and outline a number of amendments:
- South-Petiegskoie uplift has fractured block structure;

- fracture areas control the uplift structural geometry, limiting the blocks with maximum oil saturated thicknesses; thus, the uplift structural features have to be taken into account for evaluation of probable massive subsidence of the field and identify hazardous deformations that appear in the fracture zones;

- the tectonic fractures identified by the structural maps analysis for reflective horizon B at a depth of approximately $2700 \mathrm{~m}$ have predominantly north-eastward and northward direction.

In the eastern part of the field the deep fracture projection passes near the process facilities of the central base BPS, CGP, which may signify the presence of a risk zone in terms of natural geotectonic situation. However, the results of geometric leveling by profile line crossing of tectonic fractures projections for the period of survey (from 2014 to 2016) did not reveal any anomaly in the behavior of the geodynamic testing ground altitude points

The analysis of engineering and geological conditions of the studied field shows the presence of vast boggy areas and soft soils (bog muck) up to $6 \mathrm{~m}$ thick in its western part. Based on the development plan for this part of the territory, there are no massive buildings and installations, apart from well cluster pad No. 1. The existing technical infrastructure (motorway, автодорога, oil flow line, overhead line routing), as well as the well pad are covered with construction soil over $3 \mathrm{~m}$ thick. Since bog muck was not excavated down to mineral soil, the artificial soil layer is resting on a 'drifting' bod muck foundation. Therefore the discovered earth surface subsidence with maximum value of $-397 \mathrm{~mm}$ in the observation point No. 17 situated in the vicinity of well cluster pad No. 1 can be caused by exogeodynamic process related with compaction of artificial soil layer on the surface of intensely bogged ground in the western part of the field [15].

The territory of oil and gas main production site in South-Petiegskoie field (with process facilities of the central production base) is located in its eastern part on the mineral foundation of the forest where the captured subsidence values 
amount to $-23 \mathrm{~mm}$ (benchmark 34) for 20142016. Relative deformation in this area does not exceed the permissible and limit values according to the requirement [16].

\section{Anthropogenic influence of the field development on the contemporary deformation processes}

$\mathrm{BS}_{6}$ horizon contains the highest amount of oil reserves in the field ( $88 \%$ of the total oilfield volume). In the course of analysis of the anthropogenic impact of hydrocarbon reserves development, key geological and production indicators as of 01.01.2016 were considered, based on the data provided by the development department of RN-Uvatneftegaz LLC.

As of 01.01.2016, 4 exploration wells and 17 production wells had been drilled and then tested. The total number of wells is 29. Starting from the beginning of the field development, 2.8 million tons of fluid was withdrawn, including 1.3 million tons of oil. The reservoir pressure analysis (based on the isobar maps) signifies the development of a draw-down in the central part with a drop from 23.0 $\mathrm{MPa}$ (initial pressure) to $17.0 \mathrm{MPa}$ (current pressure). In the oil cumulative recovery scheme modeled in isolines of quantitative production indicators, the maximum values are focused in the western part of the field. Based on the combined data of reservoir pressure schematic maps and cumulative recovery, there is evidence that in the very beginning of the field commercial development there is a distinct anthropogenic impact of hydrocarbons recovery on the contemporary subsidence process in the western part of the field (Figures 7,8).

The comparative analysis of leveling and gravimetric survey for 2014-2016 (by subsidence trough and dynamic anomalies of gravity) shows the existence of high correlation between the areas with maximum subsidence and abnormal density zones and confirms anthropogenic participation in the development of the subsidence trough (see Figure $3, b ; 5)$.

Analysis and interpretation of survey and geodetic measurements results in the SouthPetiegskoie geodynamic testing ground, taking into account the data of geological production monitoring, are required to establish the degree of the field development anthropogenic influence on deformation process, since there is a relation between the earth surface subsidence and the dynamics of reservoir pressures, fluid (oil) recovery by the key production indicators, and density properties by gravimetry.

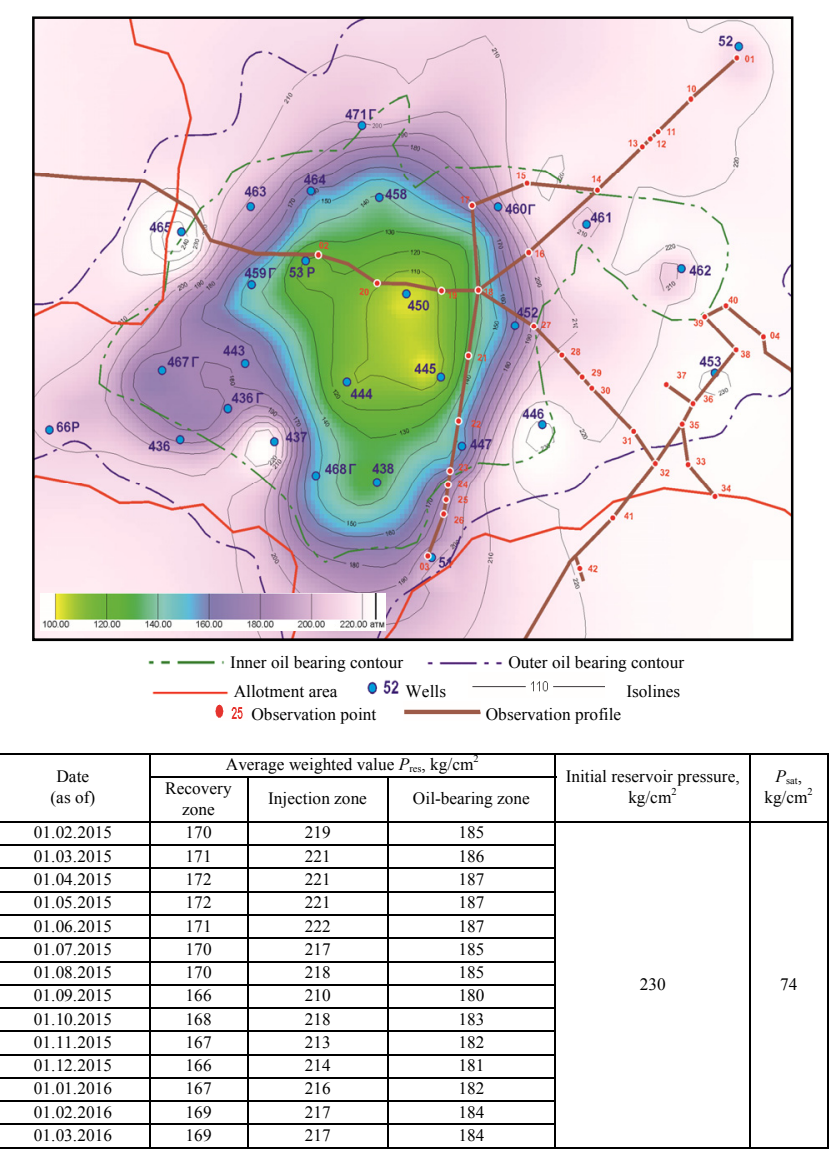

Figure 7. Isobar schematic map as of 01.02.2016 for horizon $\mathrm{BS}_{6-7}$

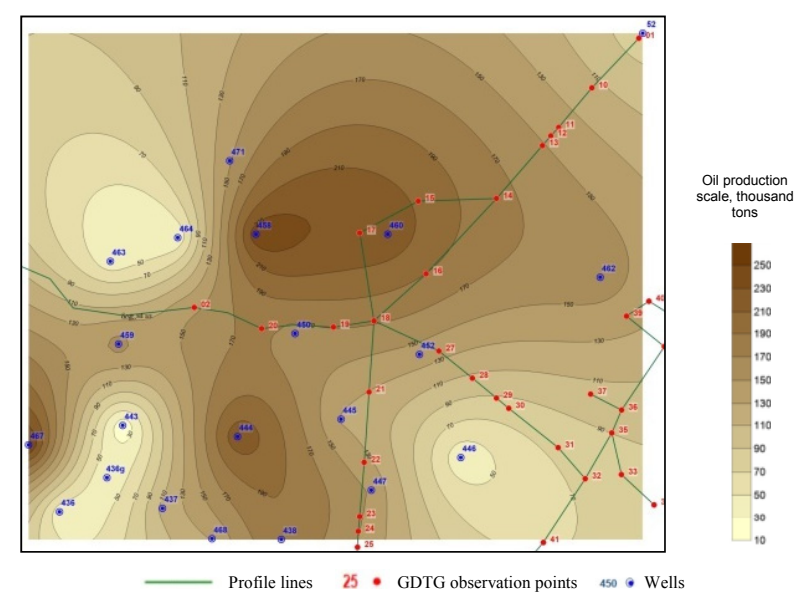

Figure 8. Schematic map of cumulative oil recovery for all horizons as of 01.01.2016. 


\section{Summary}

1. The results of third cycle of high precision geodetic measurements, obtained by way of class II geometrical leveling for the period between 2014 and 2016, signify that out of 37 GDTG altitude points, 27 were found to be degrading. This is an evidence of earth surface sustainable subsidence process above the production territory of South-Petiegskoie field.

2. The leveling results analysis allowed to build the earth surface subsidence trough with maximum value $-397 \mathrm{~mm}$ in the observation point (benchmark 17) located in the vicinity of well cluster pad No. 1. This can be related to the exogeodynamic processes of artificial soil layer compaction on the underlying massively boggy foundation in the western part of the field.

3 . The territory of the major process site of oil and gas production is located in the western part of the field above the mineral grounds of a forest where a subsidence of maximum $-23 \mathrm{~mm}$ (benchmark 34) was captured for the period between 2014 and 2016.

4. Observation points horizontal drift vectors obtained from the fata of GNSS observations for 2014-2016 have a predominantly eastern direction. Maximum values of horizontal drift were received for benchmarks $15(98 \mathrm{~mm})$ and $17(71 \mathrm{~mm})$, located in the vicinity of cluster No. 1.

5. Leveling results for crossing of tectonic fractures by profile lines did not show abnormal behavior of the geodynamic testing ground observation points, which means that the natural geological and tectonic influence has not been confirmed so far.

6. Analysis and interpretation of geodetic measurement results, natural geological and tectonic conditions and anthropogenic use of the reserves suggest that the discovered deformations were formed under the influence of natural and anthropogenic factors. The geodynamic risk area exists in the vicinity of well cluster pad No. 1.

7. The obtained results of geodynamic monitoring allow for the conclusion that there is a relation between the earth surface subsidence and the dynamics of reservoir pressures, fluid (oil) recovery by the key production indicators, and density properties anomaly by gravimetric analysis in the western part of the field.

8. To enable a more comprehensive analysis of deformation processes, the deep benchmarks network has to be augmented in the areas of the highest impact of earth surface drift. Use of remote sensing techniques (radar interferometry, or high precision macroscale aerial triangulation) can amplify the picture of deformations if conducted several times per year [17-20]. Multiple remote sensing throughout the year will help to understand the reasons of earth surface deformation, that can be related, apart from development of hydrocarbon reserves, to exogeodynamic processes such as soil freezing or thawing, spring snow melting, as well as works related to dumping or excavation of massive volumes of soil.

\section{References}

1. RD 07-408-01. Polozhenie o geologicheskom i marksheiderskom obespechenii promyshlennoi bezopasnosti i okhrany nedr [Regulations on geological and surveying industrial safety security and protection of mineral resources], available at: http://snipov.net/ c 4653 snip_109232.html.

2. RD 07-603-03. Instruktsii po proizvodstvu marksheiderskikh rabot [Instructions for the production of surveying works], available at: http:// www.infosait.ru/norma_doc/43/43121/index.htm.

3. Sistema obespecheniia geodinamicheskoi i ekologicheskoi bezopasnosti pri proektirovanii i ekspluatatsii ob"ektov TEK: metodicheskie rekomendatsii [Security system of geodynamic and environmental safety in the design and operation of FEC facilities: methodological recommendations]. Sankt-Petersburg: VNIMI, 2001, 86 p.
4. Sidorov V.A., Kuz'min Iu.O. et al. Kontseptsiia 'Geodinamicheskaia bezopasnost' osvoeniia uglevodorodnogo potentsiala nedr Rossii" [The concept "Geodynamic development safety of the potential hydrocarbon resources of Russia"]. Moscow: IGRGI, 2000, 56 p.

5. GKINP (GNTA)-03-010-02. Instruktsiia po nivelirovaniiu I, II, III i IV klassov [Leveling manual of I, II, III and IV classes]. Moscow: Roskartografiia (TsNIIGAiK), 2003.

6. GKINP (GNTA)-04-122-03. Instruktsiia po razvitiiu vysokotochnoi gosudarstvennoi gravimetricheskoi seti Rossii [Instructions for the development of high-precision gravimetric Russian state network]. Moscow: TsNIIGAiK, 2004.

7. Seigel H.O. A guide to high precision land gravimeter surveys. Ontario, 1995, $132 \mathrm{p}$. 
8. Novoselitskii V.M., Prostolupov G.V. Vektornaia obrabotka gravimetricheskikh nabliudenii $\mathrm{s}$ tsel'iu obnaruzheniia i lokalizatsii istochnikov anomalii [Vector processing of gravimetric observations to detect and locate anomalies' sources]. Materialy 1 vserossiiskoi konferentsii "Geofizika i matematika”. Moscow: IOFZ RAN, 1999, pp.104-107.

9. GKINP (ONTA)-02-262-02. Instruktsiia po razvitiiu s"emochnogo obosnovaniia i s"emke situatsii i rel'efa s primeneniem global'nykh navigatsionnykh sputnikovykh sistem [Instructions for the development of shooting justification and situations and relief shooting using global navigation satellite systems]. Moscow: FSGiK RF TsNIIGAiK, 2002.

10. Kashnikov Iu.A., Ashikhmin S.G. Mekhanika gornykh porod pri razrabotke mestorozhdenii uglevodorodnogo syr'ia [Rock mechanics in the development of hydrocarbon fields]. Moscow: Nedra, 2007, 466 p.

11. Kuz'min Iu.O. Sovremennaia geodinamika i otsenka geodinamicheskogo riska pri nedropol'zovanii [Modern geodynamics and assessment of geodynamic risk at subsurface use]. Moscow: Agentstvo ekonomicheskikh novostei, 1999, $220 \mathrm{p}$.

12. Kuz'min Iu.O., Zhukov V.S. Sovremennaia geodinamika i variatsii fizicheskikh svoistv gornykh porod [Modern geodynamics and variations of physical rock properties]. Moscow: Izdatel'stvo Moskovskogo gornogo universiteta, 2004, $262 \mathrm{p}$.

13. Petukhov I.M., Batugina I.M. Geodinamika nedr [Subsurface geodynamics]. Moscow: MGGU, 1999, p. 287.

14. Khain V.E., Lomize M.G. Geotektonika s osnovami geodinamiki [Geotectonics with the basics of geodynamics]. Moscow: Universitet, 2005, 560 p.
15. Trofimov V.T. Ekzogeodinamika ZapadnoSibirskoi plity [Exogeodynamics of the West Siberian Plate]. Moscow: MGU, 1986, 288 p.

16. SP 22.133330.2011. Svod pravil osnovaniia zdanii i sooruzhenii. Aktualizirovannaia redaktsiia SNiP 2.02.01-83 [Set of rules for the buildings' and constructures' development. The updated edition of BNaR 2.02.01-83], available: URL:http://docs.cntd.ru/ document/1200084710.

17. Filatov A., Yevtyushkin A., Vasilev Y. Geodynamic monitoring of oil-and-gas fields using radar Interferometric data. Abstract 2nd TERRABITES Symposium. Modelling the terrestrial biosphere: From Ecological Processes to Remote Sensing Observations. ESA/ESRIN, 6-8 February 2012. Frascati, 2012, p.52.

18. Ferretti A., Prati C., Rocca F. Permanent Nonlinear subsidence rate estimation using permanent scatterers in differential SAR interferometry. IEEE Transactions on Geoscience and Remote Sensing. 2000, vol.38, is.9, pp.2202-2212.

19. Hoggerl N. Repeated levelling and vertical crustal movement. Problems and results. Proceedings of the Symposium Held in Vienna, Austria, September 13-14, 1979, supl. 9, pp.201212. DOI: 10.1007/978-3-7091-8588-9 20.

20. Vasil'ev Iu.V., Iakovlev S.I., Filatov A.V. Rezul'taty monitoringa deformatsionnykh protsessov metodami vysokotochnoi geodezii, gravimetrii, radarnoi interferometrii na Samotlorskom geodinamicheskom poligone [The results of monitoring deformation processes by methods of high accuracy geodesy, gravimetry and radar interferometry in the Samotlor geodynamic testing ground]. Marksheiderskii vestnik, 2015, no.4, pp.38-44.

\section{Список литературы}

1. РД 07-408-01. Положение о геологическом и маркшейдерском обеспечении промышленной безопасности и охраны недр [Электронный ресурс]. URL: http://snipov.net/ c_4653_snip_109232.html (дата обращения: 24.06.2016).

2. РД 07-603-03. Инструкции по производству маркшейдерских работ [Электронный ресурс]. - URL: http://www.infosait.ru/norma_doc/43/43121/ index.htm (дата обращения: 24.06.2016).

3. Система обеспечения геодинамической и экологической безопасности при проектировании и эксплуатации объектов ТЭК: метод. рекомендации. СПб.: ВНИМИ, 2001. - 86 с.

4. Концепция «Геодинамическая безопасность освоения углеводородного потенциала недр России» / В.А. Сидоров, Ю.О. Кузьмин [и др.]. - М.: ИГРГИ, 2000. - C. 56.

5. ГКИНП (ГНТА)-03-010-02. Инструкция по нивелированию I, II, III и IV классов. - М.: Роскартография (ЦНИИГАиК), 2003. - 135 с.
6. ГКИНП (ГНТА)-04-122-03. Инструкция по развитию высокоточной государственной гравиметрической сети России. - М.: ЦНИИГАиК, 2004. - 219 с.

7. Seigel H.O. A guide to high precision land gravimeter surveys. - Ontario, 1995. - $132 \mathrm{p}$.

8. Новоселицкий В.М., Простолупов Г.В. Векторная обработка гравиметрических наблюдений с целью обнаружения и локализации источников аномалий // Материалы 1-й всерос. конф. «Геофизика и математика». М.: ИОФЗ РАН, 1999. - С. 104-107.

9. ГКИНП (ОНТА)-02-262-02. Инструкция по развитию съемочного обоснования и съемке ситуации и рельефа с применением глобальных навигационных спутниковых систем. - М.: ФСГиК РФ ЦНИИГАиК, 2002. - 55 с.

10. Кашников Ю.А., Ашихмин С.Г. Механика горных пород при разработке месторождений углеводородного сырья. - М.: Недра, 2007. - 466 с.

11. Кузьмин Ю.О. Современная геодинамика и оценка геодинамического риска при недропользовании. М.: Агентство экономиических новостей, 1999. - С. 220. 
12. Кузьмин Ю.О., Жуков В.С. Современная геодинамика и вариации физических свойств горных пород. - М.: Изд-во Моск. горн. ун-та, 2004. - 262 с.

13. Петухов И.М., Батугина И.М. Геодинамика недр. - М.: МГГУ, 1999. - 287 с.

14. Хайн В.Е., Ломизе М.Г. Геотектоника с основами геодинамики. - М.: Университет, 2005. - 560 с.

15. Трофимов В.T. Экзогеодинамика ЗападноСибирской плиты. - М.: МГУ, 1986. - 288 с.

16. СП 22.133330.2011. Свод правил. Основания зданий и сооружений. Актуализированная редакция СНиП 2.02.01-83 [Электронный ресурс]. URL:http:/docs.cntd.ru/ document/ 1200084710 дата обращения: 24.06.2016).

17. Filatov A., Yevtyushkin A., Vasilev Y. Geodynamic monitoring of oil-and-gas fields using radar Interferometric data // Abstract 2nd Terrabites Symposium. Modelling the terrestrial biosphere: From
Ecological Processes to Remote Sensing Observations. ESA/ESRIN, Frascati, Italy. 6-8 February 2012. Frascati, 2012. - P. 52.

18. Ferretti A., Prati C., Rocca F. Permanent Non-linear subsidence rate estimation using permanent scatterers in differential SAR interferometry // IEEE Transactions on Geoscience and Remote Sensing. - 2000. - Vol. 38, is. 9. P. 2202-2212.

19. Hoggerl N. Repeated levelling and vertical crustal movement. Problems and results // Proceedings of the Symposium Held in Vienna, Austria, September 13-14, 1979. - 1979. Supl. 9. - P. 201-212. DOI: 10.1007/978-3-7091-8588-9 20.

20. Васильев Ю.В., Яковлев С.И., Филатов А.В. Результаты мониторинга деформационных процессов методами высокоточной геодезии, гравиметрии, радарной интерферометрии на Самотлорском геодинамическом полигоне // Маркшейдерский вестник. -2015 . - № 4. - С. 38-44.

Please cite this article in English as:

Vasilev Iu.V. Analysis of the results of surveying and geodetic observations on geodynamic testing ground South-Petiegskoie field. Bulletin of PNRPU. Geology. Oil \& Gas Engineering \& Mining, 2016, vol.15, no.20, pp.261-269. DOI: 10.15593/2224-9923/2016.20.6

Просьба ссылаться на эту статью в русскоязычных источниках следующим образом:

Васильев Ю.В. Анализ результатов маркшейдерско-геодезических наблюдений на геодинамическом полигоне ЮжноПетьегского месторождения // Вестник Пермского национального исследовательского политехнического университета. Геология. Нефтегазовое и горное дело. - 2016. - Т.15, №20. - C.261-269. DOI: 10.15593/2224-9923/2016.20.6 